\title{
Salt Processing Project: Off-Line Analysis Methods to Meet Process Cycle Time
}

by

R. A. Sigg

Westinghouse Savannah River Company

Savannah River Site

Aiken, South Carolina 29808

D. P. DiPrete

This paper was prepared in connection with work done under the above contract number with the U. S. Department of Energy. By acceptance of this paper, the publisher and/or recipient acknowledges the U.S. Government's right to retain a nonexclusive, royalty-free license in and to any copyright covering this paper, along with the right to reproduce and to authorize others to reproduce all or part of the copyrighted paper. 
WSRC-TR-2002-00310

Page 1 of 29

$09 / 04 / 02$

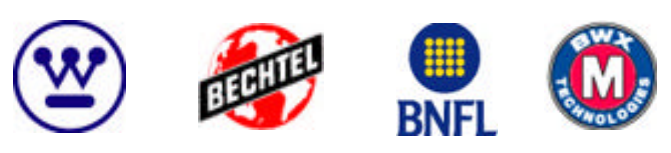

WSRC-TR-2002-00310

\title{
Salt Processing Project:
}

Off-Line Analysis Methods to Meet Process Cycle Time

\author{
R.A. Sigg and D.P. DiPrete
}

Analytical Development Section /

Savannah River Technology Center

July 2002 
This document was prepared in conjunction with work accomplished under Contract No. DE-AC09-96SR18500 with the U. S. Department of Energy.

\section{DISCLAIMER}

This report was prepared as an account of work sponsored by an agency of the United States Government. Neither the United States Government nor any agency thereof, nor any of their employees, makes any warranty, express or implied, or assumes any legal liability or responsibility for the accuracy, completeness, or usefulness of any information, apparatus, product or process disclosed, or represents that its use would not infringe privately owned rights. Reference herein to any specific commercial product, process or service by trade name, trademark, manufacturer, or otherwise does not necessarily constitute or imply its endorsement, recommendation, or favoring by the United States Government or any agency thereof. The views and opinions of authors expressed herein do not necessarily state or reflect those of the United States Government or any agency thereof.

This report has been reproduced directly from the best available copy.

Available for sale to the public, in paper, from: U.S. Department of Commerce, National Technical Information Service, 5285 Port Royal Road, Springfield, VA 22161, phone: (800) 553-6847, fax: (703) 605-6900

email: orders@ntis.fedworld.gov

online ordering: http://www.ntis.gov/help/index.asp

Available electronically at http://www.osti.gov/bridge

Available for a processing fee to U.S. Department of Energy and its contractors, in paper, from: U.S. Department of Energy, Office of Scientific and Technical Information, P.O. Box 62, Oak Ridge, TN 37831-0062,

phone: (865)576-8401,

fax: (865)576-5728

email: $\underline{\text { reports@ adonis.osti.gov }}$ 
WSRC-TR-2002-00310

Page 3 of 29

07/22/02

Authors

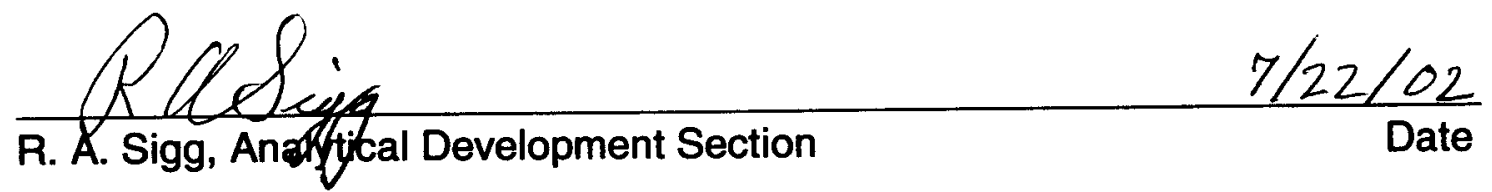

\begin{tabular}{lr} 
David $D_{1} 0$ & $7 / 23 / 02$ \\
\hline D. P. Diprete, Analytical Development Section & Date
\end{tabular}

Design Check

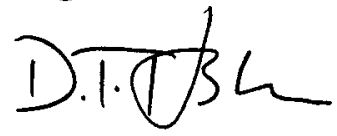

$7 / 31 / 02$

D. T. Hobbs, Waste Processing Technology Section

Date

Approvals

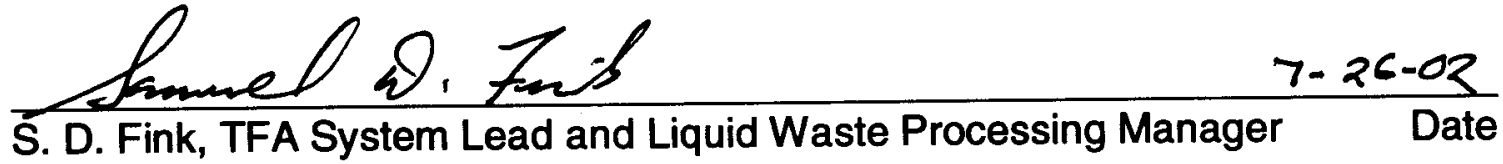

S. D. Fink, TFA System Lead and Liquid Waste Processing Manager

J. T. Carter, Director, Salt Disposition Engineering

$\frac{B / 15 / 02}{\text { Date }}$

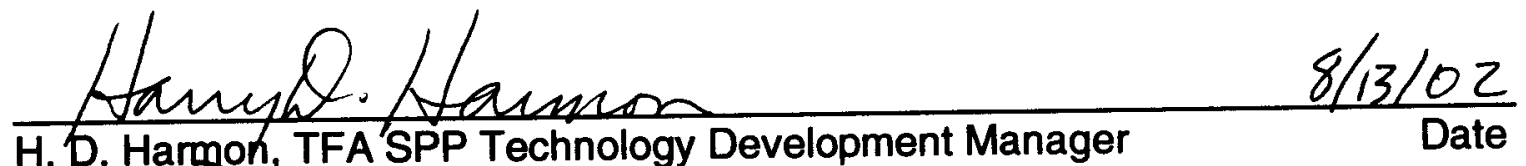

H. D. Harmon, TFA'SPP Technology Development Manager

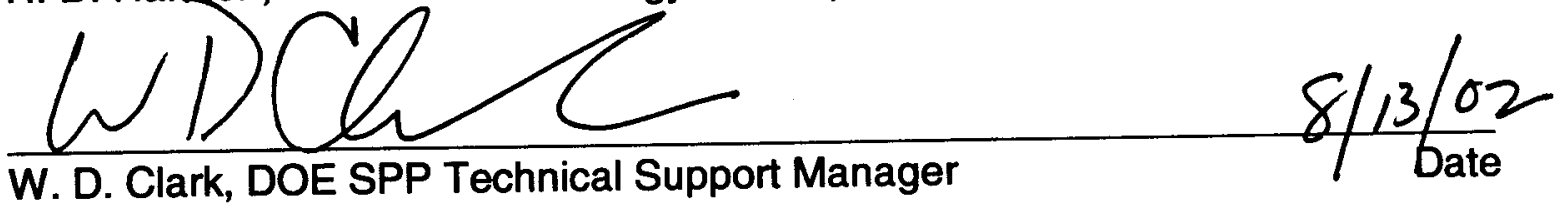


WSRC-TR-2002-00310

Page 4 of 29 $09 / 04 / 02$

\section{Table of Contents}

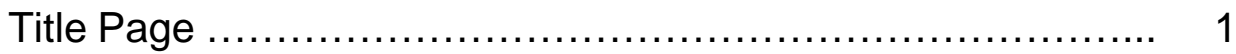

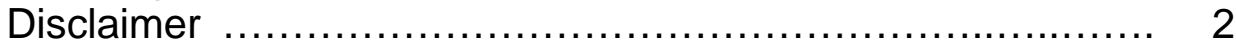

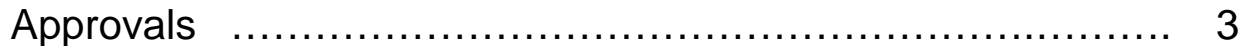

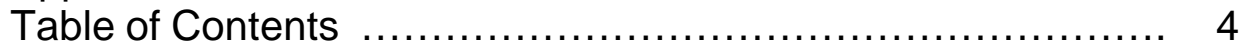

List of Figures ................................................ 5

List of Tables................................................... 5

Section:

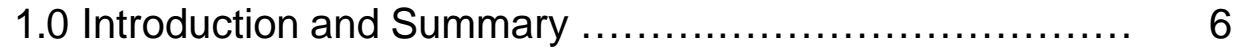

2.0 Background ........................................... 7

3.0 Turn-around Time and Institutional Realities .............. 9

4.0 Strontium-90 Methods .................................. 10

4.1 Strontium-90 Radiochemistry - Rapid Manual Method .... 10

4.2 Automated Radiochemistry for Strontium-90 ............. 13

5.0 Total Alpha Methods ..................................... 16

5.1 Automated Total Alpha Detection $\ldots \ldots \ldots \ldots \ldots \ldots \ldots \ldots \ldots \ldots . .16$

5.2 Rapid Manual Total Alpha Separation and Counting ..... 18

5.3 Alternate Total Alpha Methods ........................... 20

6.0 Conclusions ........................................... 20

7.0 Acknowledgements 21

8.0 References ............................................ 21 
WSRC-TR-2002-00310

Page 5 of 29

$09 / 04 / 02$

\section{List of Figures}

Figure 1. Simplified sketch of a bypass loop for an off-line sampling station. 23

Figure 2. Syringe filtration and resin cartridges for rapid cesium removal 23 and strontium separations.

Figure 3. Strontium-90 detection limits and SWPF requirements versus counting times using rapid manual radiochemistry and liquid scintillation counting .

Figure 4. Photograph of a liquid scintillation counter with alpha / beta discrimination and automated sample changer.

Figure 5a. Diagram of an automated Technetium-99 radiochemistry station developed for Hanford RPP.

Figure 5b. Photograph of an automated Technetium-99 radiochemistry station developed for Hanford RPP.

Figure 6. PIPS diode for total alpha measurement in process solutions...

\section{List of Tables}

Table 1. Radionuclide Concentrations …............................. 27

Table 2. Strontium-90 Methods: Comparison of Features ................. 28

Table 3. Total Alpha Methods: Comparison of Features ................. 29 
WSRC-TR-2002-00310

Page 6 of 29

$09 / 04 / 02$

\subsection{Introduction and Summary}

The Salt Waste Processing Facility (SWPF, Ref. 1) requires analyses to verify that strontium and total alpha content of treated wastes meet Saltstone Processing Facility (SPF) Waste Acceptance Criteria (WAC, Ref. 2). The SWPF will require that results are available in time to meet process cycle requirements.

SWPF personnel sought on-line and at-line monitors (Ref. 3) to follow trends in strontium-90 and alpha concentrations in order to track process performance. While an on-line method is under development at the Pacific Northwest National Laboratory (PNNL, Ref. 4), it has yet to be demonstrated. This report describes offline methods that will not be subject to some of the concerns about and limitations of on-line/at-line methods. Presently, less-rapid off-line technologies are the baseline methods.

Trace levels of alpha emitters ( $20 \mathrm{nCi} / \mathrm{g})$ and the strontium-90 beta emitter $(\sim 120$ $\mathrm{nCi} / \mathrm{g}$ ) must be monitored in the presence of 4 to 5 orders of magnitude higher levels of cesium-137. Although, the response times requested for off-line monitors (20 hours) differ from those given for the on-line/at-line monitors (6 hours) described in Reference 1, the measurement goals are otherwise unchanged. The accuracy of values reported by the monitoring systems need to be within $25 \%$ of the actual concentration ( $95 \%$ confidence).

The SWPF requires high reliability and low maintenance for all of its processes if it is to provide feed to the Defense Waste Processing Facility at rates needed for efficient operation and to meet the Federal Facilities Agreement. This report discusses reliability and maintenance issues, and it points to industrial and production-support experiences whenever possible. Where automation is considered, special attention is paid to reliability and maintenance issues.

We gathered information and method recommendations from different DOE sites. A video conferencing workshop, specifically designed to meet the analysis needs of SWPF, was held in March 2002. Experts from across the DOE complex who participated in the conference included Moses Attrep (Los Alamos National Laboratory), John Keller (Oak Ridge National Laboratory), Oleg Egorov (Pacific Northwest National Laboratory), Gary Troyer (Hanford), and Sam Fink, David DiPrete and Raymond Sigg (Savannah River Technology Center).

This report summarizes information from that conference and from subsequent discussions. Recommendations of off-line technologies to meet SWPF goals are made. The report compares advantages and disadvantages of a variety of approaches including rapid radiochemical separations, automated analytical-scale processing systems, and radiation measurement tools.

Strontium-90. Two methods were suggested for strontium-90. Savannah River Technology Center (SRTC) approached the analytical need with an expedient manual radiochemical method and liquid scintillation counting. A second method, proposed by Pacific Northwest National Laboratory (PNNL), would apply automated 
WSRC-TR-2002-00310

Page 7 of 29

$09 / 04 / 02$

radiochemical separations and flow-through counters. Potential advantages and disadvantages of each approach are discussed.

Both of these off-line radioanalytical approaches should meet process needs for strontium-90 data, and either method will provide results in less than one hour. We favor the manual method because it is simple and can be performed rapidly by cross-trained facility operations personnel. It can also be more readily supported by Laboratory Department or by SRTC personnel.

Alpha. Oak Ridge National Laboratory (ORNL), PNNL and SRTC personnel suggested three different methods for rapid alpha analyses. While all three organizations use Inductively Coupled Plasma mass spectrometry (ICP-MS) for long-lived alpha emitting radionuclides, this technique may be inappropriate for rapid turn-around process control.

Under separate funding, PNNL is developing membrane-coated, ion-implanted silicon detectors for monitoring alpha emitters in solution. Though this work is in its early stages, they believe that the detectors may meet SWPF requirements and should be sufficiently rugged for process monitoring applications.

SRTC proposes rapid chemical removal of cesium-137 interference followed by alpha/beta discriminating liquid scintillation counting (LSC) for total alpha determination.

While details on each of the strontium-90 and alpha methods are provided later, we recommend adopting rapid manual methods at SWPF due to the site's experience with supporting robust manual methods at satellite laboratories.

Any of the off-line analytical approaches should meet the process cycle time requirements; however, institutional challenges to achieving rapid turn around are recognized. Issues related to collecting the samples, obtaining Radiological Control clearance, and transporting samples to a facility laboratory could introduce excessive delays. Savannah River Site (SRS) personnel, experienced in managing satellite laboratories, suggested ways to minimize these delays.

This report also discusses secondary-waste-generation rates, sample sizes, equipment and approximate equipment costs.

\subsection{Background}

As the SRS vitrifies High Level Waste currently stored in its storage tanks to meet the Federal Facilities Agreement, it needs to minimize the amount of glass produced for economic reasons. The volume of salt sent to the vitrification facility will be minimized by

- Removing radionuclides from the salt, and

- Sending the decontaminated salt solution to the SPF. 
WSRC-TR-2002-00310

Page 8 of 29

$09 / 04 / 02$

SWPF is being designed to accomplish this goal, and research and development programs are in progress to support the design (Ref. 1). Concentrations of key radionuclides in product solutions from each stage of the SWPF process must be monitored to assure that the levels of decontamination meet the SPF Waste Acceptance Criteria.

The SRS plans to use the addition of monosodium titanate (MST) to remove portions of the soluble uranium, plutonium, neptunium, and strontium contained in the waste stream (Ref. 1). Design efforts require an understanding of the rate and equilibrium loading of these components as a function of temperature, ionic strength and mixing to support the reactor designs. Initial data from batch reactor studies indicated that the MST reaction kinetics require more than the 24 hours assumed in the design basis to achieve equilibrium resulting in larger batch volumes. The program, therefore, required additional information on the kinetics for radionuclide removal under proposed process conditions. The original SRS implementation scheme using MST allowed sufficient time to remove the radionuclides. In contrast, the current process options shorten the contact time for the sorbent to 24 hours before filtration occurs based on kinetics data at $5.6 \mathrm{M}$ sodium. Strontium removal occurred rapidly under alkaline conditions with no apparent influence from the presence of competing sorbates such as actinides. Of the actinides, plutonium and neptunium removal proved most important to satisfying the requirements for total alpha activity in the decontaminated salt solution. In general, MST exhibited slower removal rates for plutonium and other actinides than observed for strontium. Testing indicated that the actinides compete for sites on the MST. Both uranium and neptunium exhibit much higher solubility in alkaline solutions than plutonium. Consequently, the extent and rate of plutonium removal depended strongly on the total actinide concentration. Hence, while the current pre-conceptual designs achieved the requirements for radionuclides, the use of MST limited the process cycle times and equipment size.

The proposed design requires verifying the removal of strontium and the actinides prior to removal of radiocesium by the process. Thus, the program requires development of appropriate analytical monitors to meet these objectives.

Table 1 presents a predicted clarified salt solution composition based on feed solution and the estimated process effectiveness for one of the proposed processes. Though a new permit is under development through discussions with the South Carolina Department of Health and Environmental Control (SCDHEC), the table includes WAC limits as of 2/25/2002 (Revision 3 of the WSRC 1S Manual, Procedure 4.01). Requirements for decontamination factors may change, reducing the extent of removal needed.

Performance requirements, established for monitoring "clarified salt solution" product from filtered solutions after strontium and alpha removal, are those required to assure that decontaminated salt solution meets SPF WAC (Ref. 2). Minimum detection levels for strontium-90 and alpha emitting isotopes are specified; plutonium-238, -239, -240, neptunium-237, americium-241, and curium-244 are of particular concern and the uranium isotopes are of lesser concern. 
WSRC-TR-2002-00310

Page 9 of 29

$09 / 04 / 02$

The Tank Focus Area (TFA) requested that candidate off-line analytical separation and measurement technologies be recommended for SWPF process control.

The process requires technologies that

- provide final analytical results in less than 20 hours,

- are robust,

- have documented equipment reliability and maintenance requirements if possible, and

- meet specified detection limits and accuracy requirements.

Discussions between colleagues at ORNL, Los Alamos National Laboratory (LANL), PNNL and SRTC were held in March 2002. While this report documents these discussions and an assessment of off-line technologies that were summarized for TFA and Salt Processing Project personnel in April 2002, it also incorporates additional technical detail.

\subsection{Turn-Around Time and Institutional Realities}

The discussion of off-line analytical methods will show that strontium-90 and alpha analyses can be accomplished in less than one to two hours (depending on the level of QA required) once the sample is received for analysis. Analytical Laboratories Department provides a full-service 24-hours/day process laboratory. However, transporting samples from other site facilities to the laboratory often takes one or two shifts depending on priorities set for the driver and availability of radiological control personnel. If transport issues are removed, meeting the 20-hour response-time requirement is straightforward. A laboratory located at the SWPF would eliminate transport delays.

The analytical procedures described in this report are simple enough that they can be performed either by dedicated technicians or by facility operators. Having the operators is an attractive option because:

- Substitute laboratory technicians may not be immediately available at a laboratory at the SWPF in case of absence (illness, etc.),

- Process operators are always present if the process is operating,

- The laboratory workload should not justify a full-time dedicated technician for these methods.

A simple bypass loop (e.g., Figure 1) can deliver process material to a shielded sample station for off-line analyses. If a laboratory is available at the SWPF, Advanced RadWorker trained personnel at the facility can move radioactive materials from the collection station (contamination area) to the analysis location (contamination area) through a radiological buffer area. A radiological hood will be required regardless of whether manual or automated methods are selected for the analyses. 


\subsection{Strontium-90 Methods}

ORNL, PNNL and SRTC use Eichrom, Inc. Sr-Resin for strontium radio-chemistry. Over the last decade, methods using this resin have claimed the position of being the most widely used in the DOE complex for analytical-scale strontium separations. Strontium methods using the resin are rapid, simple and reliable.

A rapid manual method and an automated method are presented. The following discussion describes these methods and Table 2 presents a side-by-side comparison of their features. In either case, tests are needed to determine whether organic chemicals in some SRS tanks require an oxidation pretreatment step. Strontium is typically present in basic tank waste as a carbonate.

Method requirements are a 20-hour turnaround with a $120 \mathrm{nCi} / \mathrm{g}$ detection limit and quantification at $25 \%$ with a $95 \%$ confidence interval.

\subsection{Strontium-90 Radiochemistry - Rapid Manual Method}

\subsection{1_Cesium-137 Removal Pretreatment Step}

The proposed manual methods for strontium-90 and for alpha monitoring include a cesium-removal pretreatment step. Early cesium removal reduces personnel dose rates (cesium-137 is the most significant contributor to external-whole-body-dose rates from these waste solutions) for subsequent sample handling. The step also reduces measurement interferences by about three orders of magnitude.

A number of effective cesium-removal agents are available. To minimize secondary waste, testing and development of an analytical-scale caustic side extraction method (e.g. caustic side solvent extraction (CSSX, Ref. 5) or SuperLig resins (Ref. $6)$ ), in which back-extracted cesium is returned to the process is very attractive.

Organic waste may be returned to the process if an analytical-scale CSSX is used.

However, other cesium-stripping steps such as those using ammonium molybdophosphate (AMP, Ref. 7), potassium hexacyanocobalt ferrate (Ref. 8, also used in 3M Corporation's Cesium Disks), or resorcinol formalydehyde (Ref. 9) could be applied. Reference 10 provides a recent and more comprehensive review of cesium removal options from supernate solutions.

\subsubsection{Strontium-90 Separation and Counting}

Rapid strontium separation would be followed by immediate liquid scintillation analysis of strontium-90 beta. Though many laboratories wait for over a week to allow ingrowth of the yttrium-90 daughter prior to counting, this is not necessary; strontium-90's beta can be counted directly by scintillation counting methods immediately after separation.

An outline of steps for the proposed manual method follow: 
WSRC-TR-2002-00310

Page 11 of 29

$09 / 04 / 02$

- Cesium strip,

- Acidify,

- Add stable strontium carrier,

- Extract from 3M HNO 3 (conditioned column, etc.)

- Rinse interfering ions from column with $3 \mathrm{M} \mathrm{HNO}_{3}(10$ to $20 \mathrm{~mL}$ )

- Elute strontium with dilute $\left(\sim 10^{-4} \mathrm{M}\right)$ nitric acid,

- Count using liquid scintillation beta spectrometry,

- Radiochemical yields can be determined by running spiked duplicates or by analyzing for strontium carrier

Figure 3 shows disposable syringes and Sr-resin cartridges that can be used to accomplish the separations. To eliminate potential cross-contamination, the syringes and cartridges would not be reused. Total time for the separation is about 20 minutes.

The manual method will meet SPF required strontium-90 detection limits in relatively short LSC count times (Figure 2) assuming easily-achieved radiochemical yields, counting efficiencies and detector backgrounds. Expected activity levels of $120 \mathrm{nCi} / \mathrm{g}$ can be measured with the required sensitivity and precision in less than one minute. Figure 4 shows a liquid scintillation counter with an automatic sample changer. A smaller manually operated discrete-sample LSC spectrometer could also be used. The total analysis including data entry and quality assurance can be completed in less than an hour.

If screening data for process control purposes are required, some steps can be omitted. The method outlined will give quantitative results.

\section{Estimated Sample Size:}

1- to $2-\mathrm{mL}$

\section{Sensitivity:}

$\sim 0.2 \mathrm{nCi} / \mathrm{g}$ following a 1-minute count. This is much better than process requirements $(120 \mathrm{nCi} / \mathrm{g})$; see Figure 2. Estimated accuracy 5\% RSD.

\section{Secondary Waste:}

Estimated aqueous waste volume: $10 \mathrm{~mL}$

Cesium strip solutions could be returned to process to minimize waste. 6-mL vials may be used to minimize liquid-scintillation-cocktail waste.

Solid waste disposable items: two $10-\mathrm{mL}$ syringes, syringe filter, one $\mathrm{Sr}$ -

Resin cartridge.

Job-control waste (gloves, hood floor paper, ...). 


\section{Analysis time:}

Less than one hour. Exact values depend somewhat on data-quality objectives; that is, fewer analytical steps may be needed to satisfy screening for process control than for regulatory analyses.

\section{Hardware:}

Liquid scintillation counter.

Approximate cost estimate: $\$ 30 \mathrm{~K}$ to $\$ 45 \mathrm{~K}$ depending on sample changer options.

\section{Reliability:}

Excellent. This is a proven method for a variety of sample matrices.

However, tests are needed to determine whether organic compounds in some SRS tanks will require additional analytical pretreatment steps.

LSC QA protocols and spike samples are run periodically to confirm method performance. The frequency is dependent on data quality objectives. Method chemicals are prepared in advance and are tested using control samples.

\section{Staffing:}

The method may be performed by process operators who are also trained as Advanced RadWorkers.

\section{Advantages:}

All materials contacting the radioactive sample are disposable. Chances of cross-contamination are greatly reduced.

Liquid scintillation spectra give better indication of the presence of any interfering radionuclides, should they be present, than crushed solid scintillants.

The LSC counter can be located in a radioactive material area (RMA) rather than a contamination area $(\mathrm{CA})$. If maintenance is required, it is simpler than for a flow-through counter in a CA hood. LSC QA protocols are run daily.

Since it is similar to methods used at other site laboratories, it should be easily supported by Analytical Laboratories Department or by SRTC.

Method chemicals are prepared prior to analysis, and tested with control samples.

The method is robust. 
WSRC-TR-2002-00310

Page 13 of 29

09/04/02

If experience shows that changes to the procedure are needed or beneficial, changes are more easily incorporated with manual methods.

\section{Disadvantages:}

More hands-on work is required than with the automated method.

While either strontium-90 method easily meets process cycle time requirements, the automated method provides results more rapidly.

Though the amounts of secondary wastes are minimal, more are generated than with the automated method.

\subsection{Automated Radiochemistry for Strontium-90}

PNNL has focused on automating several radiochemical methods (e.g., Ref. 11) in recent years. Their latest effort is development of an automated monitor for technetium-99 (Ref. 12) in support of feed pretreatment for Hanford's River Protection Program (RPP) vitrification plant.

The proposed strontium-90 method for SWPF automates (using flow-injectionanalysis techniques) what an analyst would do using typical Eichrom Sr-Resin techniques. It would update PNNL's earlier strontium method with current equipment and software. The apparatus is assembled from commercially available components (hardware costs $\sim$ \$50K).

Steps for the proposed automated method include:

- Sample Preparation

Sample digestion (if required to oxidize organics)

Sample is acidified prior to oxidation to improve oxidation kinetics. A persulfate oxidation carried out in a 5-mL open-vessel microwave with a vent line for $90 \mathrm{sec}$. These steps were automated for the RPP Technetium-99 monitor.

Due to the high organic content of many Hanford waste solutions, the automated technetium-99 monitor (Figures $5 a$ and $5 b$ ) includes a batch acidic microwave digestion system. Additional studies are needed to determine whether such a step is required for strontium analyses of low-organic SRS wastes.

If oxidation is not required, sample is acidified for Sr-Resin use.

- Separation

Automated chemistry steps are similar to those outlined in the manual method; Eichrom Sr Resin is used. Although the columns are reused, the 
WSRC-TR-2002-00310

Page 14 of 29

09/04/02

system includes an automated column switching capability to compensate for potential column degradation.

- Strontium-90 Detection

Flow-through scintillation detection using either solid or liquid flow cells are proposed. The solid scintillant cells, using granulated lithium glass

scintillator, are used in the technetium-99 monitor; these would avoid use of cocktails.

\section{Estimated Sample Size:}

1- to 2-mL including wash solutions for sample delivery lines.

\section{Sensitivity:}

To be determined. $0.5 \mathrm{nCi} / \mathrm{g}$ should be easily achieved. The value will depend on counting time and elution flow rate.

Initial estimates indicate that the required detection limit can be achieved with a several minute (1-5 minute) count

\section{Waste:}

20- to 50-mL / sample waste volumes are estimated. If necessary, smaller waste volumes may be possible through miniaturization.

\section{Analysis time:}

Estimated $\sim 10$ minutes, though faster measurements may be possible.

Times will be somewhat dependent on $\mathrm{QA} / \mathrm{QC}$ requirements. The method can be adapted for rapid screening with less extensive QA/QC.

\section{Hardware:}

Flow-through scintillation counter

Open-vessel microwave oven (may not be necessary for strontium)

Control computer

Computer controlled pumps/valves

Approximate cost estimate: $\$ 50 \mathrm{~K}$

\section{Software:}

Most of the code written for the RPP technetium monitor can be reused for strontium. 
Reliability:

To be determined. A prototype RPP technetium monitor has been tested for about two years in non-continuous use with good reliability. Tests are continuing at PNNL.

Performance verification by spike additions can be automated. The frequency can be set depending on data quality objectives.

\section{Staffing:}

The method may initially require support by PNNL personnel while SRS personnel become familiar with its maintenance. Process operation personnel should be trained in routine operation of the instrument.

\section{Advantages:}

Much of the hands-on work is eliminated.

While either strontium-90 method easily meets process cycle time requirements, the automated method provides results more rapidly.

Smaller amounts of secondary waste are generated than with the manual method.

\section{Disadvantages:}

Chances of sample cross-contamination are greater because materials (pumps, valves, tubing, separation columns, ...) are reused.

If interfering radionuclides remain:

- The flow-through counter that was automated for the RPP technetium monitor does not provide an energy spectrum to recognize their presence.

- If another vendor's flow-through beta spectrometer is used, beta-energy information is severely degraded by granulated solid scintillant flow cells. If liquid scintillation flow cells are used, the spectra are degraded because cell tubing diameters are typically much less than the range (penetrating distance) of the betas.

If maintenance is required:

- It will be more difficult because the equipment, other than the computer, would be located in a CA hood; it may be contaminated. At the present time, maintenance requirements are uncertain. The device has not been run continuously for extended times on process solutions at Hanford or at SRS.

- Support by PNNL personnel may be required. Local technical support is not presently available. 
WSRC-TR-2002-00310

Page 16 of 29

$09 / 04 / 02$

If experience shows that changes to the procedure are needed or beneficial, they are more difficult to implement than with manual methods.

\subsection{Total Alpha Methods}

Our colleagues at ORNL and LANL commented that they are unaccustomed to having significant alpha activity in supernate solutions. ORNL mentioned that the highest alpha activity that they have seen is well below $1 \mathrm{nCi} / \mathrm{g}$.; however, they also noted that they don't have as much plutonium as SRS. LANL asked how SRS defines soluble alpha, because their experience has been with actinides associated with suspended solids. SRS (Fink) responded that observed levels of alpha are present after 0.45 -micron filtration. A previous study did not find evidence of colloids (Ref. 13); however, the study was conducted on a waste sample that had been stored for some time (not freshly drawn from the tank). Low levels of organic compounds are present in some SRS waste tanks due to kerosene / tri-butyl phosphate breakdown products (e.g., butanol), and defoaming agents (Ref. 14).

Note that the analysis methods must measure total alpha (not radionuclide specific) at WAC limits while cesium-137 is present at clarified-salt-solution concentration levels $\left(\sim 2.3 \times 10^{5} \mathrm{nCi} / \mathrm{g}\right)$. Though not discussed further here, isotope-specific analytical methods are available if they should be required on a less frequent basis in the future.

The following discussion describes automated and manual methods for total alpha determination and Table 3 presents a side-by-side comparison of their features.

\subsection{Automated Total Alpha Detection}

Silicon charged particle detectors have been used for alpha spectrometry for many years. Original versions of these detectors were produced by surface-barrier or by diffused-junction techniques. In a spin-off from the semiconductor industry, passive ion-implanted silicon (PIPS) detectors became available in the 1980s. Due to their much lower leakage currents and minimal dead layers, they have better alphaenergy resolution and lower noise. They are also much more rugged and stable than preceding silicon technologies. These features have lead to their wide use in laboratory and field applications.

Initial research on adapting PIPS detectors to monitoring alpha activity in process solutions is underway at PNNL. Figure 6 depicts a conceptual diagram of how such a detector might be used in this application.

After sample is delivered to the flow cell, it would be counted for several minutes; the flow cell would be washed between samples. Because the detectors are thin, their response to gamma rays (e.g. from cesium-137/barium-137m) is low. According to PNNL, an initial cesium-removal step may not be necessary. However, with four orders of magnitude greater cesium activity than alpha, the 
WSRC-TR-2002-00310

Page 17 of 29

absence of pulse pileup from beta and gamma activity into the alpha region needs to be demonstrated.

Under separate funding, PNNL is investigating protective coatings for the detectors and has funding for initial scoping work. Additional funding would be needed for prototype development, integration and testing. They estimate that approximately six months of development time would be needed.

While Figure 6 shows a 1- to 5-mm air gap between the detector and solution in the flow cell, work is needed to show that

- The detector isn't contaminated after extended use, or

- Accumulation of salts doesn't interfere with its performance.

\section{Estimated Sample Size:}

$1-$ to $2-m L$

\section{Sensitivity:}

To be determined: depends on diode diameter and solution density. Initial estimates indicate that the required detection limit can be achieved with a several minute (1- to 5 -minute) count

\section{Waste:}

5- to $10-\mathrm{mL}$ waste volumes are estimated.

If necessary, smaller waste volumes may be possible through

miniaturization. Solutions could be returned to process to eliminate waste.

Some job-control wastes will be produced.

\section{Analysis time:}

To be determined. Estimated $\sim 10$ minutes.

\section{Hardware:}

Standard single alpha spectroscopy unit with data acquisition module Continuous Air Monitor PIPS diode Computer controlled pumps/valves

Flow cell

Approximate cost estimate: $\$ 30 \mathrm{~K}$

\section{Reliability:}

To be determined. 
WSRC-TR-2002-00310

Page 18 of 29

$09 / 04 / 02$

\section{Advantages:}

Secondary wastes are minimal or are nonexistent. Solutions may be returned to the process.

Much of the hands-on work is eliminated.

\section{Disadvantages:}

Performance is uncertain. The method is in an early development stage.

Since cesium is not removed, potential pulse-pile-up problems need to be investigated.

Most energy information is lost in solution before reaching the PIPS detector. If other radionuclides interfere, their contribution to the signal may not be recognized.

The method may require longer counting times than the manual method. Counting efficiencies are much lower than liquid scintillation used in the manual method.

Additional counting equipment is required.

If maintenance is required, it will be more difficult because the equipment, other than the computer, would be located in a CA hood. The equipment may be contaminated. Since the method is under development, maintenance requirements are unknown. Accumulation of salts may interfere with alpha detection and may require detector maintenance or replacement.

Support by PNNL personnel may initially be required while SRS becomes familiar with supporting the instrument.

\subsection{Rapid Manual Alpha Separation and Counting}

A manual approach using LSC alpha energy and pulse shape spectrometry is proposed. No further chemical separation would be needed following cesium removal (already performed for strontium-90). Pulse shape discriminator levels can be adjusted to eliminate interferences from any residual cesium-137 beta or conversion electrons.

Direct counting by liquid scintillation sidesteps any uncertainties associated with alpha emitters chemical or physical state (i.e., it doesn't matter if alpha is complexed, colloidal ( $<0.45$ micron $), \ldots)$. Extractions are not necessary. 
WSRC-TR-2002-00310

Page 19 of 29

$09 / 04 / 02$

Tests are recommended to assure that the cesium pretreatment step does not significantly alter the alpha results. We may use AMP and a syringe filter to remove the extractant.

\section{Estimated Sample Size:}

1- to $2-m L$

\section{Sensitivity:}

Several orders of magnitude better than the required $18 \mathrm{nCi} / \mathrm{g}$.

\section{Secondary Waste:}

Small volumes ( 20-mL per sample) of liquid scintillation cocktail waste and $\sim 20 \mathrm{~mL}$ of aqueous ( 1.5M nitric acid) waste are produced. They may be disposed of at the nearby Effluent Treatment Facility.

Solid waste residues (two 10-mL syringes, one syringe filter, three small vials.)

Job control wastes (gloves, hood surface paper, ...).

No additional waste is generated from the cesium removal step. It uses another aliquot of the cesium-stripped solution used for the strontium-90 method.

\section{Analysis time:}

Separation time: several minutes at most.

Count time: 1 minute

\section{Hardware:}

Uses the same LSC counter with alpha / beta discrimination that is used for the manual strontium-90 method. There is no additional cost.

\section{Reliability:}

Expected to be excellent. Tests are needed with SWPF clarified salt solutions.

\section{Staffing:}

The method may be performed by process operators who are also trained as Advanced RadWorkers.

\section{Advantages:}

The method is very rapid and simple. It is similar to those used for routine radiological screening of many samples. 
Since cesium is removed, there are no potential pulse-pile-up problems.

Since the sample is homogenized with LSC cocktail, energy resolution is adequate to recognize the presence of interfering radionuclides.

It applies the same counting equipment as the strontium-90 method.

Local technical support is available.

\section{Disadvantages:}

Small amounts of secondary wastes (listed above) are generated.

Though some hands-on work is required, it is minimal.

\subsection{Alternate Total Alpha Methods}

While the manual method discussed above is expected to be the simplest approach that takes full advantage of equipment that will be available for the strontium-90 method, there are numerous potential alternate manual alpha analyses methods. They include:

- Alpha liquid scintillation counting following rapid alpha extraction,

- Gas-Flow Proportional Analyses following rapid alpha extractions,

- Ion-implanted silicon alpha spectroscopy analyses of extracted alpha species,

- Low-Energy Photon Spectrometry of alpha extractions, and

- Gross alpha by gas-flow-proportional counter with pulse-height and pulse-shape discrimination.

These methods may be investigated further if tests show that extractions are needed to remove residual contaminants.

\subsection{Conclusions}

Time delays in moving process materials to a central analytical laboratory are expected to be the most significant hurdle in obtaining timely strontium-90 and total alpha process control data by off-line methods for the SWPF. A satellite laboratory at the SWPF would best assure that process cycle time requirements would be met.

This report discussed rapid manual and automated off-line methods that should easily meet process cycle time requirements in the absence of institutional delays. Additional tests are needed on each of the methods to confirm their viability on SWPF process samples. The authors prefer the manual methods because 1) maintenance is simpler on equipment that is located outside of contaminated hoods, 2) local technical support is available, and 3) manual methods can be more readily modified if the need should arise. 
WSRC-TR-2002-00310

Page 21 of 29

$09 / 04 / 02$

\subsection{Acknowledgements}

The authors wish to acknowledge helpful discussions with M. Attrep / LANL, O. Egorov / PNNL, J. Keller / ORNL, G. Troyer / Hanford, L.M. Chandler / SRTC and S.D. Fink / SRTC.

\subsection{References:}

1. Savannah River Site Salt Processing Project - Research and Development Summary Report, TFA-0105, Rev. 0 (2001).

2. Acceptance Criteria for Aqueous Waste Sent to the $Z$ Area Saltstone Production Facility, WSRC 1S, Procedure 4.01, Rev. 3 (2002).

3. Task Requirements and Criteria - Saltstone Processing Facility - In-Line/OnLine Radionuclide Detection Monitor (U), Doc. No. G-TC-H-00030, Rev. 1 (2000).

4. R.L. Brodzinsky et al. "A neutron monitor for real-time determination of transuranics in a processed waste effluent stream," J. Radioanal. Nucl. Chem. 248-2, 279 (2001).

5. T.M. Bonnesen et al. "Alkaline-side extraction of cesium from Savannah River tank waste using calixarene-crown ether extractant," ORNL/TM-13704 (1998).

6. R.L.Bruening et al. " $\mathrm{Cs}^{+}$and $\mathrm{TcO}_{4}{ }^{-}$separations using molecular recognition technology," $222^{\text {nd }}$ ACS National Meeting, Chicago, IL (2001).

7. C.J. Miller, A.L. Olson and C.K Johnson, "Cesium absorption from acidic solutions using ammonium molybdophosphate on a polyacrylonitrate support (AMP-PAN)," Sep. Sci Tech 32, 37 (1997).

8. W.E. Prout, E.R. Russell and H.J. Groh, "lon exchange absorption of cesium by potassium haxacyanocobalt(II)ferrate(II)," J. Inorg. Nucl. Chem. 27, 473 (1965).

9. J.P. Bibler and R.M. Wallace, "Testing a new cesium-specific ion exchange resin for decontamination of alkaline high-activity waste," Waste Management 90 , Vol II, 747 (1990).

10.M.C. Thompson, "Pretreatment radionuclide separations of Cs/Tc from supernates," WSRC-MS-98-00601 (1998).

11.J.W. Grate, S.K. Fadeff and O. Egorov, "Separation-optimized sequential injection method for rapid automated analytical separation of $90 \mathrm{Sr}$ in nuclear waste," Analyst 124, 203 (1999).

12. O. Egorov and D.E. Kurath, "Automated 99Tc analysis in AW-101 and AN-107 'Diluted Feed' Matrixes," BNFL-RPT-020, Rev. 0 (2001). 
WSRC-TR-2002-00310

Page 22 of 29

13.D.T. Hobbs, T.B. Peters and D.J. Wheeler, "Investigation of Savannah River Site High Level Waste Solutions for Evidence of Colloidal Plutonium," WSRC-TR2001-00103 (2001).

14. R.A. Dimenna et al. "Bases, assumptions, and results of the flowsheet calculations for the decision phase salt disposition alternatives," WSRC-RP-9900006, Rev. 3 (1999). 
WSRC-TR-2002-00310

Page 23 of 29

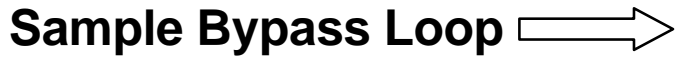

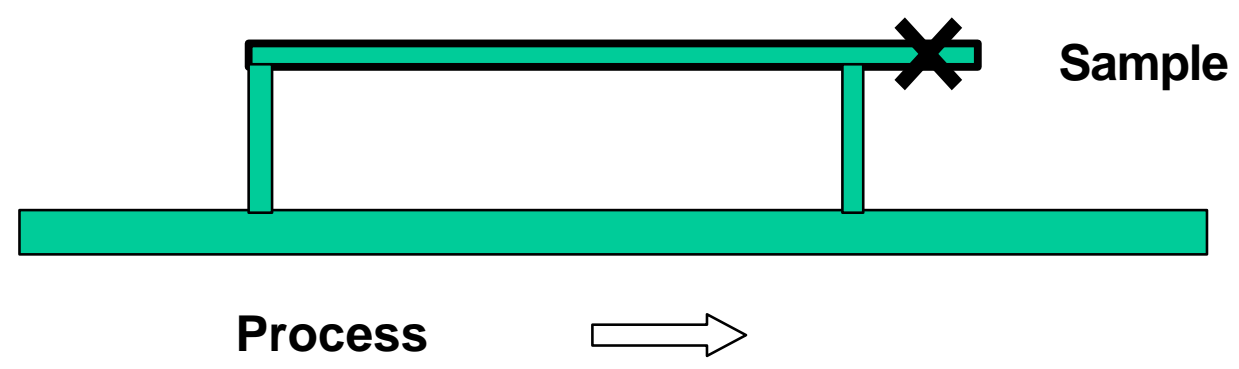

Figure 1. Simplified sketch of a bypass loop for an off-line sampling station.

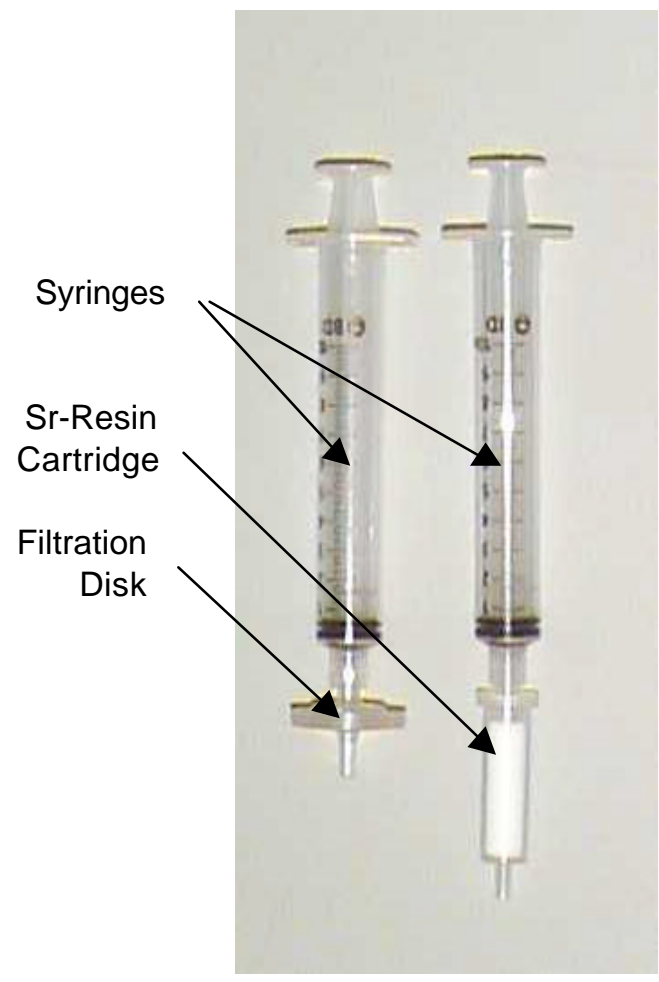

Figure 2. Syringe filtration and resin cartridges for rapid cesium removal and strontium separations. 


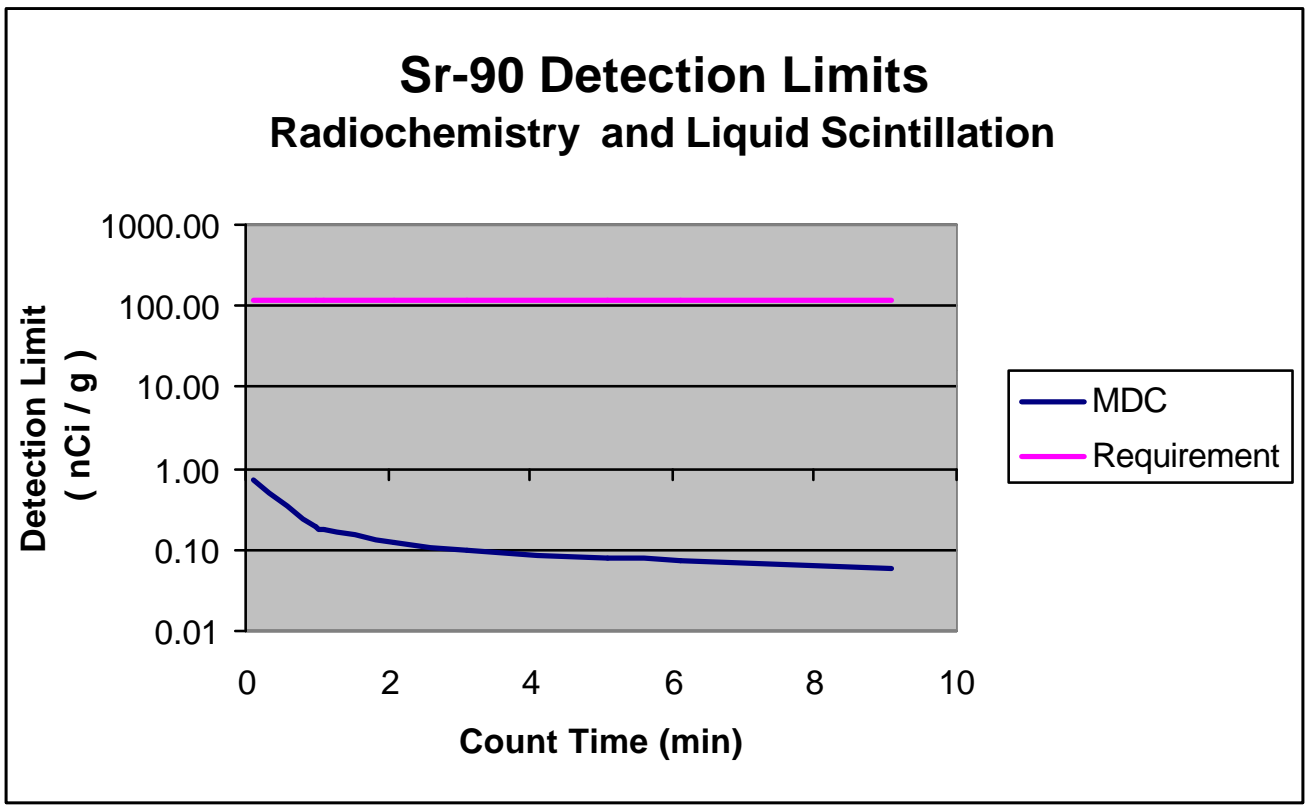

Figure 3. Strontium-90 detection limits and SWPF requirements versus counting times using rapid manual radiochemistry and liquid scintillation counting.

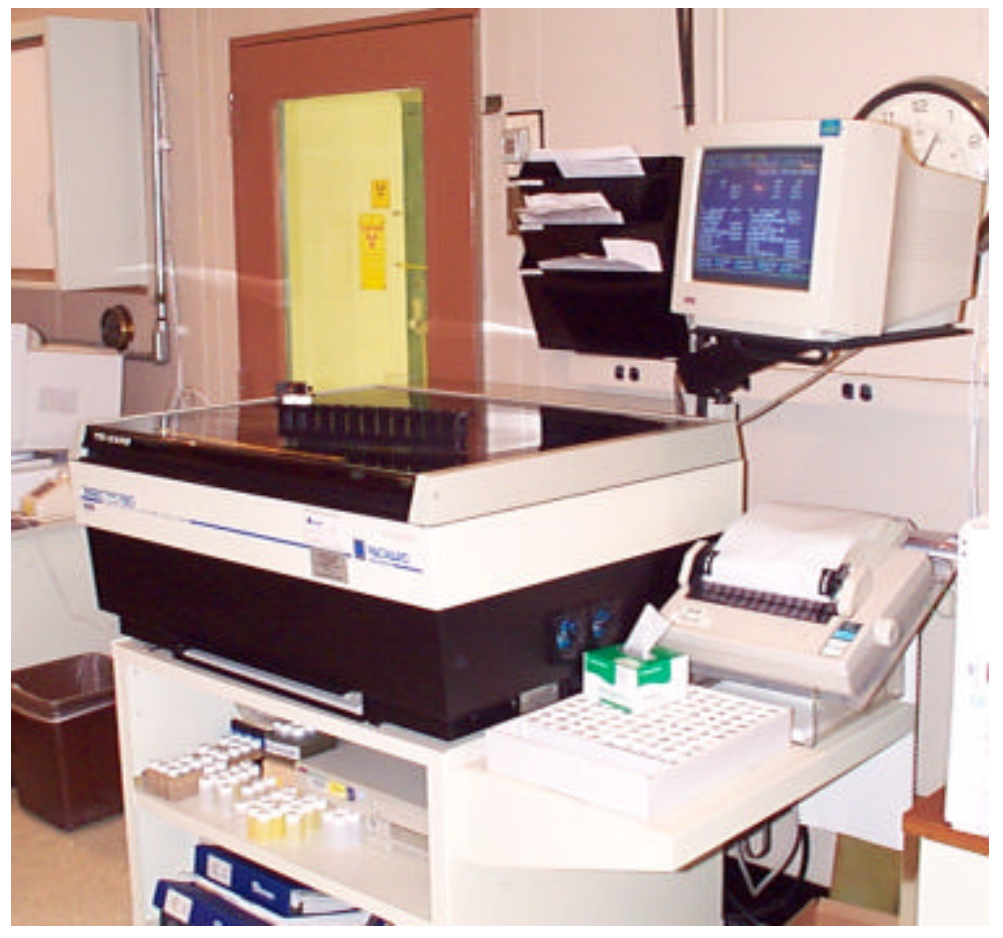

Figure 4. Photograph of a liquid scintillation counter with alpha / beta discrimination and automated sample changer. 
WSRC-TR-2002-00310

Page 25 of 29

$09 / 04 / 02$

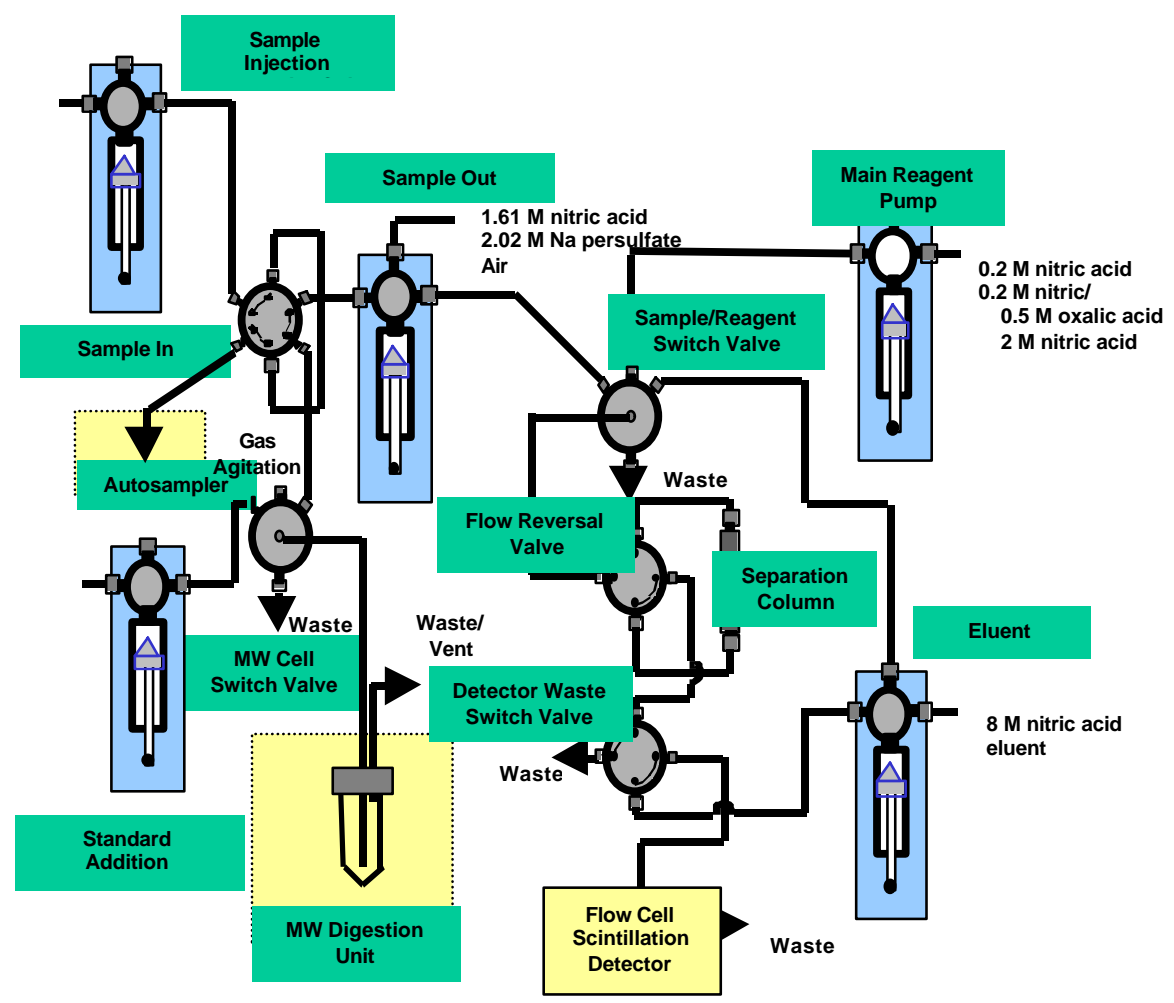

Figure 5a. Diagram of an automated Tc-99 radiochemistry station developed for Hanford RPP.

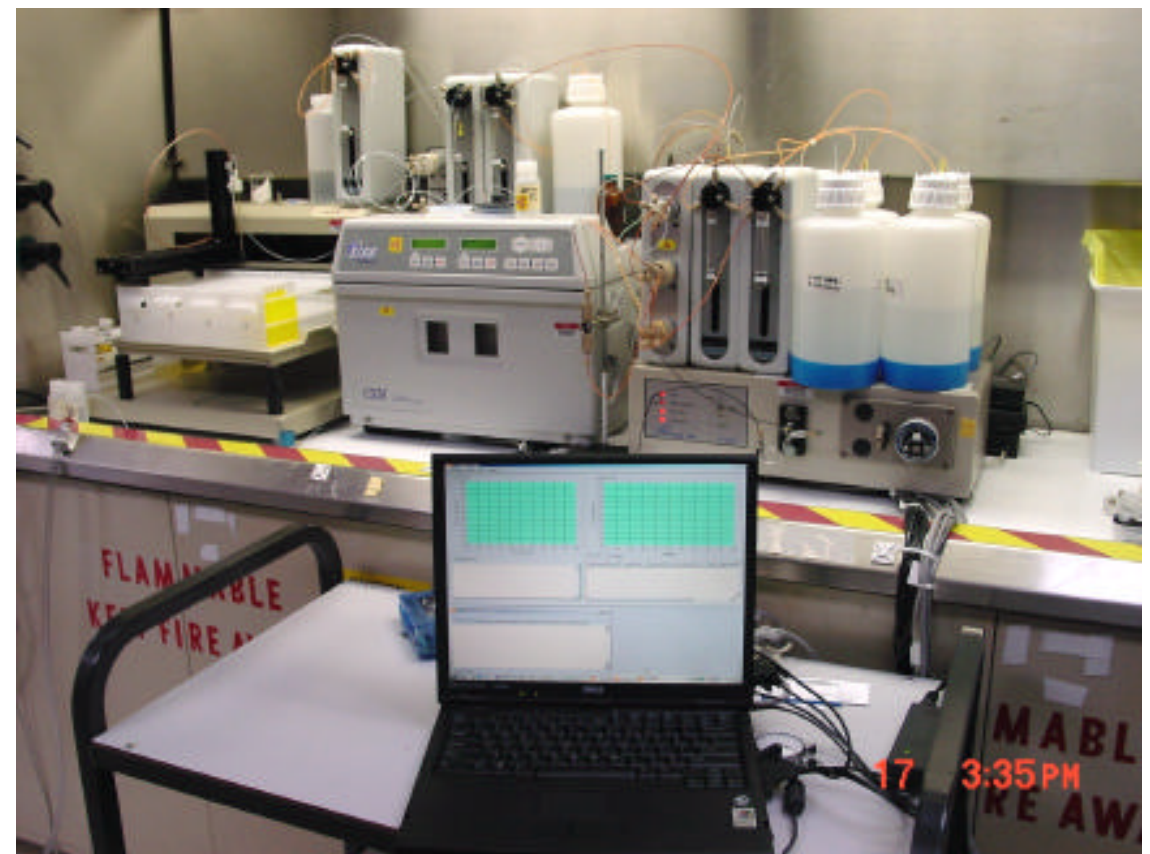

Figure 5b. Photograph of an automated Tc-99 radiochemistry station developed for Hanford RPP. 
WSRC-TR-2002-00310

Page 26 of 29

$09 / 04 / 02$

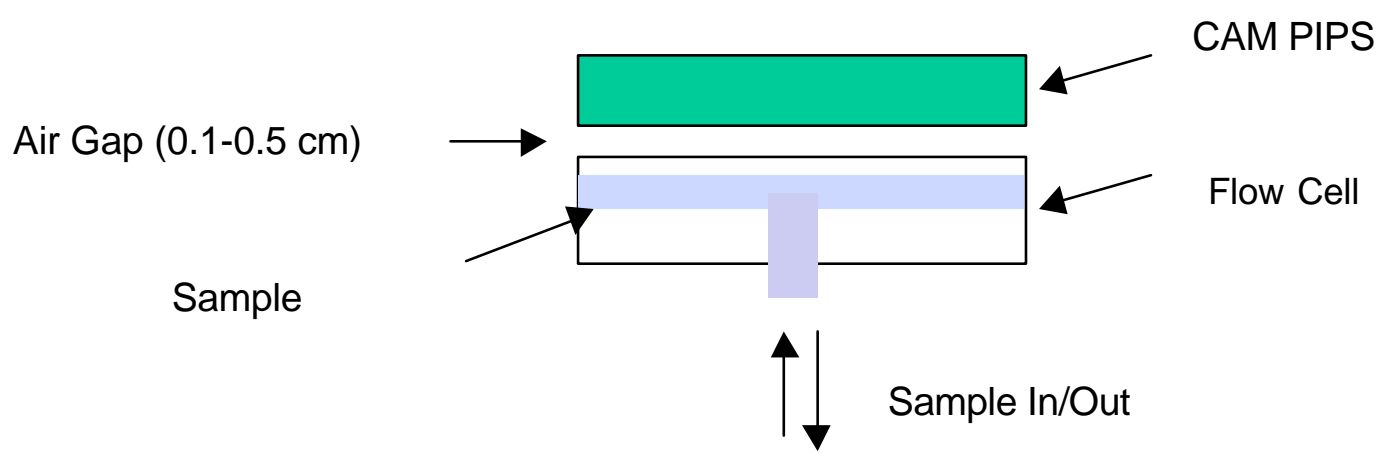

Figure 6. PIPS diode for total alpha measurement in process solutions. 
WSRC-TR-2002-00310

Page 27 of 29

09/04/02

Table 1. Radionuclide Concentrations

Radionuclide

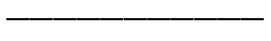

Sr-90

Cs-137

$\mathrm{U}-232$

$\mathrm{U}-234$

$\mathrm{U}-235$

$\mathrm{U}-236$

$\mathrm{U}-238$

$\mathrm{Np}-237$

Pu-238

Pu-239

Pu-240

Pu-241

Pu-242

Am-241

Am-242

$\mathrm{Cm}-244$

$\mathrm{Cm}-245$

Total "Soluble" Alpha

\begin{tabular}{ll}
$\begin{array}{l}\text { Blended } \\
\text { Feed } \\
\text { (Ci/gal) }\end{array}$ & $\begin{array}{l}\text { Blended } \\
\text { Feed } \\
\text { (nCi/g) }\end{array}$ \\
\hline
\end{tabular}

8.97E-05

$1.20 \mathrm{E}+00$

$9.14 \mathrm{E}-10$

2.10E-08

2.28E-09

3.47E-09

1.37E-07

7.68E-08

7.40E-04

6.90E-05

$1.96 \mathrm{E}-05$

3.67E-04

8.48E-09

1.63E-04

4.18E-05

$1.15 \mathrm{E}-05$

$1.50 \mathrm{E}-09$

$1.05 \mathrm{E}-03$

\subsection{E+01}

$2.35 \mathrm{E}+05$

$1.80 \mathrm{E}-04$

4.13E-03

4.49E-04

6.82E-04

2.69E-02

$1.51 \mathrm{E}-02$

$1.46 \mathrm{E}+02$

$1.36 \mathrm{E}+01$

$3.86 \mathrm{E}+00$

$7.22 \mathrm{E}+01$

1.67E-03

$3.21 \mathrm{E}+01$

8.23E-00

2.27E-00

2.95E-04

2.06E-03

\section{SPF \\ WAC Limit \\ (nCi/g)}

$1.20 \mathrm{E}+02$

$4.50 \mathrm{E}+01$

$\mathrm{N} / \mathrm{A}$

$\mathrm{N} / \mathrm{A}$

$\mathrm{N} / \mathrm{A}$

$\mathrm{N} / \mathrm{A}$

$\mathrm{N} / \mathrm{A}$

$\mathrm{N} / \mathrm{A}$

$\mathrm{N} / \mathrm{A}$

$\mathrm{N} / \mathrm{A}$

$\mathrm{N} / \mathrm{A}$

$\mathrm{N} / \mathrm{A}$

$\mathrm{N} / \mathrm{A}$

$\mathrm{N} / \mathrm{A}$

$\mathrm{N} / \mathrm{A}$

$\mathrm{N} / \mathrm{A}$

$\mathrm{N} / \mathrm{A}$

2.00E +01

Notes: Ba-137m and Y-90 are at equilibrium with their parent radionuclides in the feed, but may exist at other relative concentrations following process separations.

Values are averages of those given for SWPF feed solutions blended from SRS waste tanks in Reference 14, Appendix $\mathrm{H}$. Feed solution values are presently being reevaluated. 
Table 2. Strontium-90 Methods : Comparison of Features

\begin{tabular}{|c|c|c|}
\hline & Rapid Manual Radiochemistry & Automated Radiochemistry \\
\hline $\begin{array}{l}\text { System Information: } \\
\text { Hardware : }\end{array}$ & Liquid scintillation counter. & Flow-through scintillation counter. \\
\hline & jiquia scintulation coumer. & Open-vessel microwave oven (may not be necessary for Sr). \\
\hline Computer : & Bundled with commercial LSC & Control computer. \\
\hline $\begin{array}{l}\text { Software : } \\
\text { Cost estimate : }\end{array}$ & $\begin{array}{l}\text { Bundled with commercial LSC } \\
\$ 30 \mathrm{~K} \text { to } \$ 45 \mathrm{~K} \text { depending on options selected. }\end{array}$ & $\begin{array}{l}\text { Custom. Most code for the RPP Tc monitor can be reused. } \\
\$ 50 \mathrm{~K}\end{array}$ \\
\hline Radiological Hood & Yes & Yes \\
\hline Estimated Sample Size: & 1- to $2-\mathrm{mL}$ & $\begin{array}{l}\text { 1- to } 2-\mathrm{mL} \\
\text { Includes wash solutions for sample delivery lines. }\end{array}$ \\
\hline $\begin{array}{l}\text { Sensitivity: (120 } \mathrm{nCi} / \mathrm{g} \text { required) } \\
\text { Value depends on: } \\
\text { Count Time (min) : } \\
\text { Estimated accuracy }\end{array}$ & $\begin{array}{l}\sim 0.2 \mathrm{nCi} / \mathrm{g} \\
\text { Count time. } \\
1 \\
\sim 5 \% \text { RSD. }\end{array}$ & $\begin{array}{l}\text { O.5 } \mathrm{nCi} / \mathrm{g} \text { likely. TBD. } \\
\text { Count time and elution flow rate. } \\
1 \text { to } 5 \text { estimated. } \\
\text { TBD. }\end{array}$ \\
\hline $\begin{array}{l}\text { Analysis time : (20 hour required }) \\
\text { Depends somewhat on: } \\
\text { Screening versus regulatory } \\
\end{array}$ & $\begin{array}{l}30 \text { minutes likely. Less than one hour. } \\
\text { Data-quality objectives. } \\
\text { Fewer steps are required for rapid screening. }\end{array}$ & $\begin{array}{l}\sim 10 \text { minutes; though shorter times may be possible. } \\
\text { Data-quality objectives. } \\
\text { Can be adapted for rapid screening. }\end{array}$ \\
\hline $\begin{array}{l}\text { Performance } \\
\text { Verification : }\end{array}$ & $\begin{array}{l}\text { Spiked samples at a frequency to be determined by QA needs. } \\
\text { Routine sealed-source standards and backaround counts. }\end{array}$ & Spiked samples in an automated protocol. \\
\hline $\begin{array}{l}\text { Cross-Contamination Potential : } \\
\text { If other radionuclides interfere : }\end{array}$ & $\begin{array}{l}\text { Minimal. Disposable items contact sample. } \\
\text { Beta spectra provided to recognize if other radionuclides are present. } \\
\text { Flexible. Method easily adapted if necessary. }\end{array}$ & $\begin{array}{l}\text { Possible because columns, valves, pumps and tubing are reused. } \\
\text { Beta spectra are not available in the current system. } \\
\text { Electronics do not provide spectra. } \\
\text { Crushed solid scintillants lose energy information. }\end{array}$ \\
\hline Reliability: & Similar methods proven for a variety of sample matrices. & $\begin{array}{l}\text { TBD. RPP monitor in non-continuous use for about two years. } \\
\text { Determine whether reliability is adequate for process control. }\end{array}$ \\
\hline Staffing: & $\begin{array}{l}\text { Process operators who are also Advanced RadWorkers. } \\
\text { Some hands-on work is required. } \\
\text { Local technical support is available. }\end{array}$ & $\begin{array}{l}\text { Process operators. } \\
\text { Method eliminates much routine, hands-on work. } \\
\text { The method may require periodic support by PNNL personnel. }\end{array}$ \\
\hline $\begin{array}{l}\text { Liquid waste: } \\
\text { Aqueous waste / sample } \\
\text { LSC cocktail } \\
\text { Cs strip solution } \\
\end{array}$ & $\begin{array}{l}\sim 10 \mathrm{~mL} \text { (in nitric acid) } \\
6 \text { to } 20 \mathrm{~mL} \text {. (The Effluent Treatment Facility is nearby.) } \\
\text { Return to process, }\end{array}$ & $\begin{array}{l}\text { 20-50 mL. May reduce through miniaturization. } \\
\text { If crushed solid scintillants are used, no LSC cocktail waste is generated. }\end{array}$ \\
\hline $\begin{array}{l}\text { Solid waste } \\
\text { Analysis disposable items: } \\
\text { Job-control waste }\end{array}$ & $\begin{array}{l}\text { Two 10-mL syringes, syringe filter } \\
\text { One Sr-Resin cartridge, LSC vials } \\
\text { Gloves, hood floor paper, ... }\end{array}$ & $\begin{array}{l}\text { Sr-Resin column (frequency TBD) } \\
\text { Same but less often than manual method. }\end{array}$ \\
\hline $\begin{array}{l}\text { Support : } \\
\text { Ease of Maintenance : } \\
\text { Technical support : } \\
\text { Adaptability : }\end{array}$ & $\begin{array}{l}\text { LSC counter located in a radioactive material area. } \\
\text { Local by Analytical Laboratories Department or by SRTC. } \\
\text { Changes are more easily incorporated. }\end{array}$ & $\begin{array}{l}\text { Pumps, valves, counter and microwave oven are located in a contamination area. } \\
\text { May require PNNL. } \\
\text { Requires changes to automation protocol. }\end{array}$ \\
\hline
\end{tabular}

*Both methods require testing to determine whether pretreatment steps are needed for low organic SRS tanks. 
Table 3. Total Alpha Methods : Comparison of Features

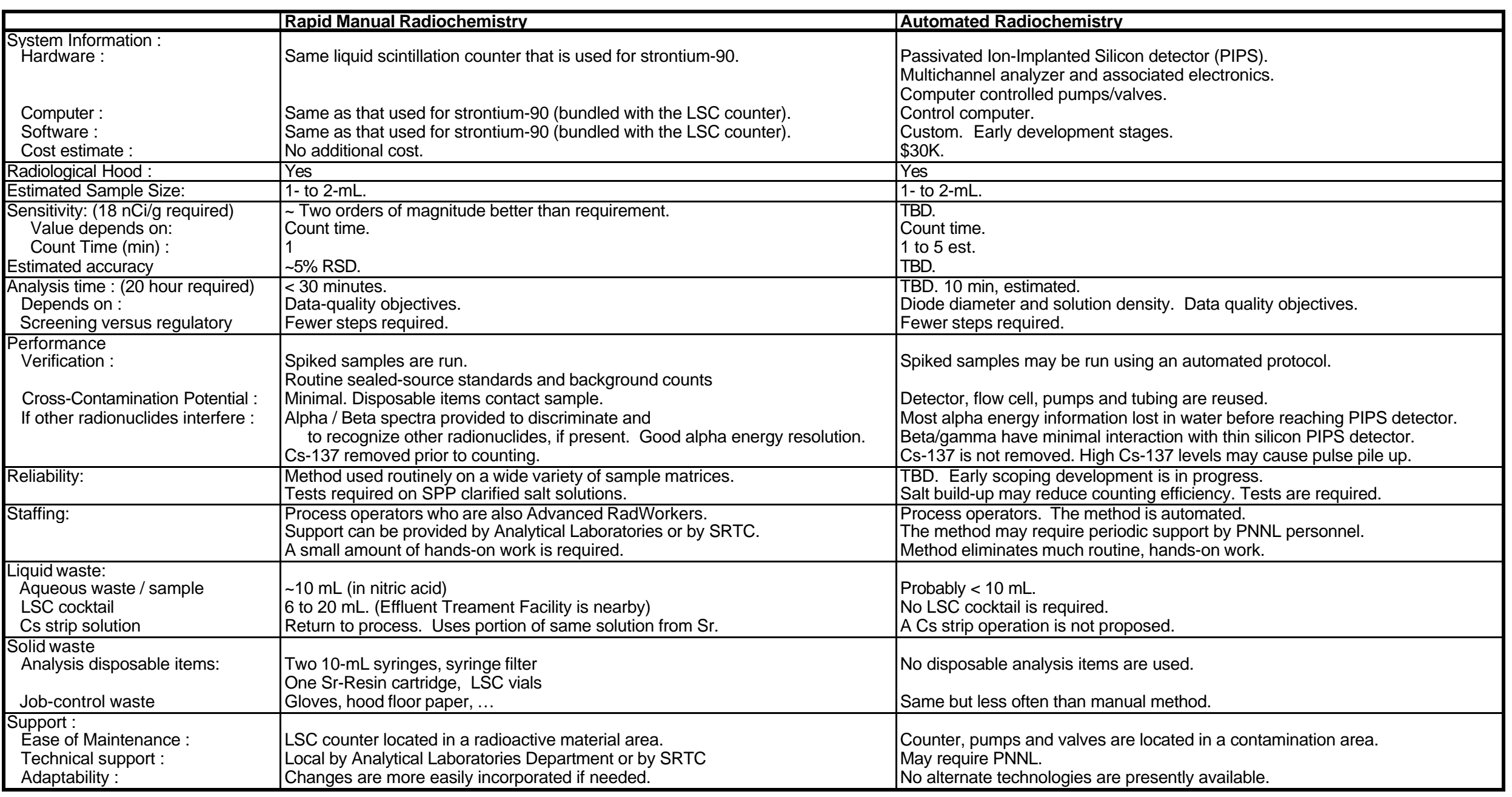

*Both methods require testing to determine whether pretreatment steps are needed for low organic SRS tanks. 